\title{
Avances, descubrimientos y potencial del microbioma intestinal en gastroenterología
}

\author{
Elena F Verdu (1) \\ Profesora, Departamento de Medicina, Universidad de McMaster, Hamilton, Canadá. \\ Vice directora, Farncombe Family Digestive Health Research Institute, Hamilton, Canadá.
}

Acta Gastroenterol Latinoam 2021;51(3):255-256

Recibido: 02/07/2021 / Aceptado: 26/07/2021 / Publicado online: 27/09/2021 / https://doi.org/10.52787/oqlg2049

En las últimas décadas, el microbioma intestinal surgió como un órgano vital adicional, capaz de realizar funciones metabólicas, inmunológicas y neuroendócrinas especializadas y complementarias a las de su huésped, el ser humano. En la mayoría de los casos, el microbioma intestinal, compuesto de billones de microorganismos integrados por bacerias, virus, y fungi (hongos), establece una relación de mutualismo con los tejidos y sistemas de su huésped. Este equilibrio puede ser alterado por muchos factores internos y externos, con consecuencias potencialmente graves, en su extremo, la invasión sistémica descontrolada. ¿Por qué, entonces hemos evolucionado para funcionar en un estado de "colonización microbiana”, no sólo en el tubo digestivo sino en la piel? La respuesta lógica es que los beneficios superan los peligros. Un ejemplo clave es la señalización por parte del microbioma al sistema immune mucoso, lo cual promueve su maduración, ${ }^{1}$ permitiendo la discriminación eficiente entre agentes infecciosos o tóxicos, o inocuos y necesarios, como los nutrientes. De esta manera el microbioma

Correspondencia: Elena F Verdu

Correo electrónico:verdue@mcmaster.ca intestinal, es clave en el mantenimiento de la homeostasis del organismo hospedador. Siendo unas de las áreas de evolución más dinámica en el campo biomédico y de investigación, actualmente la tecnología biomolecular y de secuenciación supera nuestra capacidad para interpretar los resultados. Esto provoca en investigadores, médicos y pacientes, más preguntas que respuestas. ¿Qué microbios están más adaptados a la homeostasis? ¿Existen taxones con mayor potencialidad patogénica? Debemos centrarnos en cambios de composición microbiana o funcionalidad? ¿Podemos prevenir o curar enfermedades a través de la modulación terapéutica del microbioma? ¿Qué modular, cuando aún no conseguimos definir aspectos fundamentales cómo lo que contituye un microbioma sano? En relación, a esta pregunta crítica, quizás debamos admitir que un microbioma sano no puede definirse en forma absoluta y universal, sino que es relativo a cada individuo y sus circunstancias. ${ }^{2}$

En ésta, y las siguientes ediciónes de la Revista ACTA Gastroenterológica Latinoamericana, le proponemos a nuestros lectores una serie de artículos de revisión con la intención de actualizar de manera didáctica los avances recientes en torno al microbioma intestinal en gastroenterología. Los artículos propuestos se focalizan en mecanismos específicos en situaciones patológicas definidas, con potencialidad de modulación terapéutica, y posiblemente personalizada. En esta edición, Caminero, describe el papel del microbioma intestinal en las reacciones adversas a los alimentos. La prevalencia de estas reacciones adversas está en aumento, lo cual sugiere factores ambientales como los cambios en el microbioma intestinal. ${ }^{3}$ 
Estas reacciones adversas incluyen cuadros clínicos con fisiopatología típicamente alérgica y no alérgica donde la inmunidad innata a proteínas inmunogénicas, como las del trigo, serían responsables. Caminero nos explica los mecanismos subyacentes que pueden llevar al desarrollo concreto de nuevos enfoques terapéuticos en intolerancias alimentarias a través de la modulación del microbioma intestinal. En la misma edición, Valdovinos expone un tema controvertido, y de gran importancia clínica, el uso de probióticos en una de las condiciones más frecuentes en gastroenterología, el síndrome de intestino irritable.

En anticipación a las próximas ediciones de la Revista ACTA Gastroenterológica Latinoamericana, De Palma \& Bercik, abordarán el tema del microbioma en el síndrome del intestino irritable desde un punto de vista mecanístico, complementando la revisión clínica de Valdovinos, y ayudando a comprender la compleja base fisiopatólogica en la generación de síntomas. Rueda \& Pinto-Sanchez, centrarán su discusión en la evidencia del uso de probióticos en la enfermedad celíaca, analizando la información de estudios básicos y clínicos, incluyendo meta-análisis recientes. Finalmente, Santiago-Badenas \& Verdu planterán la hipótesis y debatirán la evidencia sobre el uso de biomarcadores microbianos pre-clínicos en colitis ulcerosa.

No hay duda que el microbioma intestinal es un capítulo reciente en medicina. Sin embargo las técnicas moleculares de secuenciación y multi“omics", los modelos animales libres de gérmenes ("germ-free"), el cultivo y aislamiento de organismos anaeróbicos, y las técnicas de detección del viroma, fagoma y fungoma han avanzado en forma acelarada. Esto ha permitido la acumulación de un gran volumen de información que ha enriquecido el entendimiento de la patología digestiva de manera inesperada. El desafío reside ahora en la traslación a la esfera clínica, y el desarrollo de protocolos para la el diagnóstico precoz a través de biomarcadores asociados al microbioma, y la intervención preventiva y terapéutica utilizando bioterapias que optimicen las interacciones entre el microbioma intestinal y su huésped.

\section{Aviso de derechos de autor}

\section{(C) (2) 2021 Acta Gastroenterológica (C) (1) Latinoamericana. Este es un artículo BY NC SA de acceso abierto publicado bajo} los términos de la Licencia Creative Commons Attribution (CC BY-NC-SA 4.0), la cual permite el uso, la distribución y la reproducción de forma no comercial, siempre que se cite al autor y la fuente original.

Cite este artículo como: Verdu EF. Avances, descubrimientos y potencial del microbioma intestinal en gastroenterología. Acta Gastroenterol Latinoam. 2021;51(3):255-6. https://doi.org/10.52787/oqlg2049

\section{Referencias}

1. Zhao Q, Elson CO. Adaptive immune education by gut microbiota antigens. Immunology. 2018;154(1):28-37.

2. Shanahan F, Ghosh TS, O’Toole PW. The healthy microbiome-what is the definition of a healthy microbiome? Gastroenterology. 2021;160:483-94.

3. Caminero A, Meisel M, Jabri B, Verdu EF. Mechanisms by which gut microorganisms influence food sensitivities. Nat Rev Gastroenterol Hepatol. 2019;16(1):7-18. 


\title{
Updates on Mechanisims and Future Potential of the Intestinal Microbiome in Gastroenterology
}

\author{
Elena F Verdu (1) \\ Porfessor, Department of Medicine, University of McMaster. Hamilton, Canadá. \\ Associate Director, Farncombe Family Digestive Health Research Institute. Hamilton, Canadá.
}

Acta Gastroenterol Latinoam 2021;51(2):257-258

Received: 02/07/2021 / Accepted: 26/ 7/2021 / Published online: 27/09/2021 / https://doi.org/10.52787/oqlg2049

The intestinal microbiome has emerged as a vital organ, capable of performing complex metabolic, immune, and neuroendocrine functions that impact its mammalian (human) host. We have evolved to establish a mutualistic relationship with our gut microbiome, which remains largely beneficial to the host throughout the life span. However, many factors can perturb this peaceful equilibrium, and his has led to the prevailing concept that the gut microbiome can participate as driver of inflammation and gut dysfunction, contributing to gastrointestinal disease. On the other hand, this hypothesis has opened new diagnostic and therapeutic opportunities in gastroenterology.

One clear well known mechanism that benefits the hosts, are the microbial cues, particularly in early life, that lead to maturation of the immune system, ${ }^{1}$ instructing how to differentiate between potentially harmful agents, and innocuous antigens, such as those from

Correspondence: Elena F Verdu

Email:verdue@mcmaster.ca the diet. In the past decades we have witnessed an accelerated development of new generation techniques to study and characterize the intestinal microbiome, both compositionally and functionally. Overall, the technical capacity to explore the microbiome has advanced so rapidly, that it has somewhat outpaced our capacity for translating this enormous body of knew knowledge into clear practical applications in medicine. It is thus fair to say that more questions than answers remain, but that is the essence of science. Can we identify which microbes are more adapted to maintenance of homeostasis or to pathogenic pathways? Should we focus on understanding the conditions that trigger transformation from a commensal to opportunistic pathogen? Are we capable of applying the knowledge learned to prevent or treat disease? How and what to treat when fundamental questions such as what constitutes a healthy microbiome, ${ }^{2}$ have not been answered?

In this, and the next issue, of Revista ACTA Gastroenterológica Latinoamericana, we will feature a series of articles addressing the key role of the intestinal microbiome in the pathogenesis, as well as potential diagnosis and therapy of defined gastrointestinal conditions.

The prevalence of food sensitivities, which imply an immune underlying pathogenesis and could be allergic or autoimmune, such as celiac disease, and food intolerance have significantly increased in the past years. ${ }^{3}$ The increase is so rapid, that environmental factors related to the microbiome, have been proposed. In the current issue of Revista ACTA Gastroenterológica Latinoamericana, Caminero describes the microbial mechanisms underlying 
the development of food intolerance and sensitivities, which could be targeted with novel biotherapeutics to better treat these conditions. In this same issue Valdovinos provides an insightful review on the clinical application of probiotics in one of the most common conditions in gastroenterology, the irritable bowel síndrome. The area remains controversial, and more robust clinical trials are needed to identify specific probiotics that will benefit the clinically heterogeneous IBS. In the following edition of Revista ACTA Gastroenterológica Latinoamericana, De Palma \& Bercik address the role of the intestinal microbiome in IBS, from a mechanistic perspective, increasing our understanding of microbial pathways leading to symptom generation. Rueda \& Pinto-Sanchez, argue on the clinical evidence for the use of probiotics in celiac disease, from basic studies to recent meta-analyses. Finally, Santiago-Badenas \& Verdu discuss the hypothesis and current evidence for the development of pre-clinical microbial biomarkers in ulcerative colitis.

The intestinal microbiome, without doubt, is a new chapter in medicine. However, the speed at which the technology to characterize the microbiome (compositionally and functionally) continues to advance, outpaces our capacity to implement the insights gained into clinical practice. The challenge for the future will be to successfully apply the knowledge accumulated into new diagnos- tics, and biotherapeutics, taking into account specific microbiome-host interactions in a personalized manner.

\section{Copyright

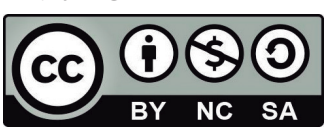

(C) 2021 Acta Gastroenterológica latinoamericana. This is an openaccess article released under the terms of the Creative Commons Attribution (CC BY-NC$S A$ 4.0) license, which allows non-commercial use, distribution, and reproduction, provided the original author and source are acknowledged.

Cite this article as: Verdu EF. Updates on Mechanisims and Future Potential of the Intestinal Microbiome in Gastroenterology. Acta Gastroenterol Latinoam. 2021;51(3):257-8. https://doi.org/10.52787/oqlg2049

\section{References}

1. Zhao Q, Elson CO. Adaptive immune education by gut microbiota antigens. Immunology. 2018;154(1):28-37.

2. Shanahan F, Ghosh TS, O'Toole PW. The healthy microbiome-what is the definition of a healthy microbiome? Gastroenterology. 2021;160:483-94.

3. Caminero A, Meisel M, Jabri B, Verdu EF. Mechanisms by which gut microorganisms influence food sensitivities. Nat Rev Gastroenterol Hepatol. 2019;16(1):7-18. 